\title{
MANAGERS' PROPENSITY FOR PARTICIPATIVE DECISION MAKING IN BANGLADESH AND MALAYSIA: A COMPARATIVE STUDY
}

\author{
Lt Col Md Enamul Islam, psc* \\ Postgraduates Center, \\ Limkokwing University of Creative \\ Technology, Malaysia
}

\author{
Barrister Shahrina Razzaque Juhi \\ Faculty of Business Administration, \\ Bangladesh University of Professionals
}

\author{
Dr Valliappan Raju \\ Post Graduates Center, \\ Limkokwing University of Creative Technology \\ * Corresponding Author
}

Article DOI: https://doi.org/10.36713/epra5466

\begin{abstract}
Subordinate participation in the decision-making process has been practised extensively in developed countries for a long time. Less is known about developing and least developing nations. This study assesses the propensity for participative decision making among the managers of Bangladesh and Malaysia. The hypotheses test propensity scale among the managers of both the countries and if mangers of Malaysian Industries demonstrate more propensity than Bangladeshi managers. In the process, the study assesses the similarities and differences of opinion concerning four dimensions of the participative decision-making process, i.e. organisational effectiveness, organisational culture, perceived power-sharing and mutual trust. The quantitative survey research approach found that individual differences significantly determine one's propensity for the participative decision-making process. In an independent samples t-test, Malaysian managers have shown a more significant level propensity for participative decision making than Bangladeshi managers. The study also shows that there is a significant relationship between trust and organisational culture as two important dimensions of PDM. The results of this study arise a case for managers of both countries to question their expectations about employees and disparagingly examine whether their predispositions influence their decision-making practices. The findings may provide business leaders of both the courtiers in these contexts with an understanding of the possible adaptation of the concept of the participative decision-making process.
\end{abstract}

KEYWORDS: Propensity for Participative Decision-Making Process, Productivity, Managing People at Work, Power Sharing, Bangladesh, Malaysia

\section{INTRODUCTION}

Participative decision-making (PDM) is well researched, and most talk about a subject in industrial relations in the west. However, little is known in developing and least developing countries. Alsughayir (2016, p-65) explicitly mentioned that "Though PDM has been researched in developed countries, the generalizability of those findings across cultures remains an issue". PDM has little academic attention in the least and developing countries (Zubair et al. 2015). Industries that have developed a culture to allow employees to take part in the decision-making process have increased in productivity and less resistance to change (Chan et al. 2016; Elele and Fields 2010; Parnell 2010; Timming 2015). This trend advocate that many employees desire a more significant role in decision making and PDM is likely to promote job satisfaction, increase productivity, sustained organisational performance, organisational learning, improved leader effectiveness, and ultimately increase overall performance.

Bangladesh is one of the least developed countries that has all positive signs of becoming an 
emerging developing nation in the Asian economy. The country has remarkable growth in industrialisation since the inception of the free economy from the late nineteen century (Al-Amin et al. 2018; Mahmood and Absar 2015; Sayed et al. 2017). Despite an abundance of technical and nontechnical human resource, the productivity in the manufacturing industry is not up to the mark (Dutta and Islam 2016). Farhana and Cheazlantaib (2018) in their recent study opined that entrepreneurs' extreme desire to make a profit, the relentless effort for production cost reduction, the stubborn attitude of lower and middle-level managers have resulted in skirmishes, riot, and chaos in the promising industry. The textile industry, on the other hand, is more sensitive, often workers are found on the street making protest and claiming their legal right. Employees voice in the decision-making process technique should have been used to mitigate the unwanted situation (Mohiuddin 2018).

The Malaysian economy is growing rapidly. The country is about to touch the threshold of development in all index maintained by the United Nations. Rapid industrial growth, peaceful industrial relation, workers social security, and recognised workers voice in the decision-making process has boosted the industrial prosperous (Koen et al. 2017). Employees enjoy great freedom in expressing their opinion on decision-related to industrial productivity (Nor et al. 2017; Salaudin and Shahrul Nizam 2014).

A comparative study may assist Bangladeshi business entrepreneurs in understanding as to what is going wrong and how PDM can be ensured in business enterprises. This study joins a queue in the propensity for participative decision-making (PPDM) initiated by Parnell (2010) and Parnell and Bell (1994) to asses managers' predisposition for adapting or rejecting PDM in the organisation concerning four dimensions of PDM. The authors considered organisational effectiveness, organisational culture, perceived power-sharing, and managers' commitment as dimensions of PDM. However, literature (as will be revealed in an upcoming discussion in the literature review) mutual trust between worker and manager has a significant relation with ones' proclivity for PDM. Therefore, this study tried to identify this relationship in the Bangladeshi context.

This objective of this quantitative research study is to understand the similarity and difference of opinion of managers PPDM and to find out the propagated relation between trust and PPDM. The following sections highlight research on PDM and the management context of the two Asian nations (Malaysia and Bangladesh). The results of the survey are analysed and presented, followed by discussion and future research guidelines.

\section{LITERATURE REVIEW 2.1 The PDM}

PDM refers to consensus in decision-making. Here individuals or groups can have a say in the decision-making process. Their opinion/s are valued, recognised, and the decision is taken jointly. PDM is concerned with how the employee can participate in organisational decision-making system, the degree of employee involvement, and how they will involve or make a contribution (Ritesh, Rambir, and Kumar 2015). PDM is crucial for achieving organisational effectiveness and increase productivity. Participative decision-making increases job satisfaction and morale if an ideal participatory decision-making environment can be created in an organisation (ScottLadd and Verena 2004). Managers should take necessary endeavours to ensure that a balance in created among task attributes, performance, and reward which will give them satisfied and committed employees. (S Pavan Kumar and Saha 2017) in their study opined that PDM has a strong correlation with job satisfaction and organisational effectiveness. (Parnell and Bell 1994) Have developed a propensity scale, best known as Propensity for Participative Decision-Making Scale (PPDM). The authors claimed that they have successfully measured managers' penchant for a participative decisionmaking system considering two dimensions of PDM (organisation effectiveness and power-sharing attitude) in manufacturing industries in the USA. Later (Parnell and Crandall 2000) have evaluated the previous propensity scale developed by Parnell and Bell (1994) and added two more dimensions (organisational culture and manager's commitment).

\subsection{The PPDM}

While PDM refers to the procedure or mechanism of a system where members of an organisation participate in discussing various issues and finding alternative solutions, PPDM refers to the predisposition or willingness of the persons involved in PDM. Scholars suggest that employees often desire for PDM regardless of their levels of influence on the organisation. Employees will always want to participate in PDM, but their desire will not have any positive impact on decision-making outcomes if management does not view their desire positively (Tandin 2015). Russ (2013), in his study, explicitly narrated that managers' attitude to solicit others' input in the decision-making process is crucial for organisational success. PDM is usually a process where participant at all level of any organisation meets together to discuss issues about them or the organisation. Here everyone has a voice and can contribute. PDM is democratic. None should be overenthusiastic or forcing others to implement his or her idea or opinion forcibly.

One's propensity for PDM demonstrates his concern regarding PDM outcome. Researcher around 
the globe has proofed that PDM has an absolute specific benefit. Many factors are influencing the development of PDM. Recent studies revealed that managers' propensity is significant for PDM success (Parnell 2010; Parnell and Crandall 2000; Parnell, Koseoglu, and Dent 2012; Tandin 2015).

\subsection{PDM in Malaysia}

Employee participation in decision making is widely used and common practice in Malaysia. Employee participation in the form of a quality circle, suggestion team, total quality management, labourmanagement committees, join consultative councils are widely used in Malaysia (Salaudin and Shahrul Nizam 2014). Malaysia is considered as a perfect place to study PDM (Raida 2013). In a study of PDM in manufacturing industries in Batu Phahat, Malaysia, Chan et al. (2016) argued that managers in manufacturing industries of the understudy manufacturing industry had shown a moderate level of PDM. A study on PDM conducted by Carolyne (2014, p-8) while citing (Parasuraman et al. 2011) argued that "in Malaysia employee involvement is referred to as indirect participation, which takes place through an intermediary of employee representative bodies."

PDM is focused and moderately researched in Malaysia. There is a mixture of multinational companies operating in Malaysia, having entrepreneurs from both developed and developing nations. These international companies mostly influence Malaysian business culture. As such, PDM, which was once best known and practised in the west, is now available in Malaysia as well (Nor et al. 2017; Parasuraman 2007; Raida 2013). Singh (2009) while discussing the manager's willingness for PDM has argued that Malaysian managers in private sector undertakings have more propensity towards PDM than public sector undertakings. Shaed et al. (2015) in a review paper on the PDM study opined that PDM study in Malaysia was confined to find out the correlation with job-satisfaction, productivity, trust, organisational performance. Their research also identified that the Malaysian manager's PPDM mainly focused on indirect participation.

\subsection{PDM in Bangladesh}

PDM study in the context of Bangladesh is infrequent. There is no unified database from where someone can get a complete picture of a PDM study in Bangladesh. However, some studies could be noticed in the internet search. Mohammad Nurul, Mohammad Tahlil, and Sadia (2010) research on human resource management practice in Bangladesh opined that, like other developing nations, human resource management study did not find enough space in scholarly kinds of literature in Bangladesh. Islam and Eva (2017) conducted the most recent research on the application of McGregor's Theory $\mathrm{X} / \mathrm{Y}$ in Bangladeshi Banking industry opined that managers in most bank branches behave rudely with the employees. Despite having the best opportunity to make the right quality decision (since maximum employees in the banks are highly educated) in a participative decision-making style, most managers take solo decisions and forced to implement those. Managers stubborn attitude, unwilling to share decision-making power, bare minimum negotiation skill, knowledge and experience of employees regarding $\mathrm{PDM}$ are found posing impediment for a PDM environment (Al-Amin et al. 2018; Hasan Riyadh and Zaman 2016; Hossan, Rahman Sarker, and Afroze 2012; Md. Nurun Nabi et al. 2017; MENENDEZ et al. 2013).

Managers' willingness to adapt PDM concepts seriously hamper organisational effectiveness. Talukder, Blackman, and Abdullah (2016) in their study could critically examine the role of experience in decision making and commented that managers' bias towards the PDM environment is very meagre in Bangladesh. The hierarchal clan type organisational set up gives too much power to the managers, not realising that employees can put up better options in decision- making to find alternative solutions. Ali, Khaleque, and Hossain (1992), in their study, opined that management in Bangladesh still holds the traditional view of the management system. Manages of manufacturing industries in Bangladesh like to use centralisation of authority and control. Managers believe that decision making is their prerogative, and only management should make the decision, and employees should obey those without question. A tripartite decision-making concept as propagated by the International Labour Organisation (ILO) is in practice, especially in the garments industries. The worker's representatives, the employee, and representative from the government should seat together once in every three months to discuss dispute if any. This concept is otherwise known as "Social Dialogue". In Bangladeshi business culture, values, and ethics such as obedience, submission, adhering seniors order, and respect for authority are highly emphasised (Arumugam and Balasundaram 2010).

\subsection{The PPDM and Trust}

To measure specific psychological attributes, one should if possible, have a tool to measure it. It saves time, effort, and money if already examined, and a successful measurement scale is available in the literature (Sekaran and Bougie 2016, p-197). This study has used a PPDM scale developed by Parnell and Bell (1994), a few years after 1994, the scale was modified by Parnell and Crandall (2000). The scale was also used by a few other researchers to determine managers' propensity in various cultural dimensions (Parnell 2010; Parnell et al. 2012; Ritesh et al. 2015). The modified scale has 20 items with general demographic data. The author studied four 
dimensions, i.e. organisational effectiveness, organisational culture, power-sharing, and commitment. However, the literature suggests that trust is a very crucial dimension that determines one's propensity for decision making. This study also considered trust to be another essential dimension leaving managers' commitment dimension unattended.

Tzafrir and Dolan (2004, p-128) developed a scale to measure the degree of trust between employer and employee. The scale has 16 items considering a five-point Likert scale ranging one as strongly disagree while five as strongly agree. The author argued that the trust scale could measure the level of trust in any organisation. The author explicitly mentioned that "by asking respondents to indicate their level of trust in the manager or employee, and to give their perception of that manager or employee, managers can compare each department's average trust score with the scores of other departments." This study will compare the average trust score of managers of both countries.

\subsection{The Rationale for This Study}

In the "lens" (or "keyhole") comparison, in which PDM in Bangladesh is weighing less heavily than PDM in Malaysia. The PDM in Malaysia is used as a lens through which to view PDM in Bangladesh. In recent studies, researchers have shown interest to study PDM in Malaysia in various dimensions. The literature review identified that Malaysian industrialists have positively agreed to follow consensus in decision-making that gives them increased productivity and enhanced organisational effectiveness. The study conducted by Salaudin and Shahrul Nizam (2014) suggest that Malaysian Multinational Companies have increased productivity following PDM techniques. Over a few years, the Malaysian industry has rapid productivity growth. Malaysian industrial culture is influenced by Japanese and Chinese culture that promote consensus in decision-making in both formal and informal ways. On the other hand, Bangladeshi managers are yet to view the PDM positively (Khandakar, Khadija, and Sarmin 2018).

M. A. Akkas, Anannay Chakma, and Mohammad Ikbal Hossain (2015) argued that managers' unwillingness, mistrust between employer and employee, fear of losing executive power, and powerful political influence are primarily responsible for poor industrial relation. Ali et al. (1992) studied how a forced PDM in textile industries failed in 1991. The authors argued that managers' stubborn attitude and poor academic knowledge are the main barriers in the implementation of PDM in Bangladesh. Even after many years, researchers have found that not much improvement has taken place in managerial attitude for PDM in Bangladesh (Islam, Nilufar, and Mohammad 2018; Khandakar et al.
2018). Parnell et al. (2012) compared the manager's propensity between the USA and Turkish managers. These countries are not at par in any social, economic, or organisational culture. A comparative study is better suggested where comparable items should be close in nature and dimension. Therefore, this study finds it is suitable to compare the managerial attitude for PDM in Bangladesh and Malaysia since both nations have similarities in the context of religion, national, and organisational culture. Thus, a hypothesis can be derived that Malaysian managers are likely to demonstrate a higher-level score in PPDM and trust scales than Bangladeshi managers $\left(\mathbf{H}_{\mathbf{1}}\right)$.

PPDM study was confined with four dimensions of PDM (Parnell and Bell 1994; Parnell and Crandall 2000). However, the literature suggested that trust between managers and employees is also an essential dimension of PDM. One's propensity can not be confirmed concerning PDM if there are a communication gap and mistrust exits (Russ 2011, 2013). An empirical study is essential to identify if there is any relationship between trust and PPDM. Thus, we can hypothesise that a significant relationship exists between trust and $\operatorname{PPDM}\left(\mathbf{H}_{2}\right)$.

\section{RESEARCH METHODOLOGY}

This study follows a cross-sectional quantitative research approach. Data were collected at one point in time. Both Parnell and Crandall's (2001) refined the PPDM scale, and Tzafrir and Dolan (2004) trust measuring scale were used to identify the degree of managers PPDM in both countries concerning the four dimensions of PDM. Demographic questions were also included, such as age, gender, service length, managerial experience, and position in the organisation to get the demographic profile of the respondents.

Samples from Bangladesh were selected from eight industries from the manufacturing sector and two industries from the service sector. Samples were randomly chosen with assistance from the senior manager (focal point officer) from each industry. The questionnaire was translated into the Bengali language by a bilingual academic who is also a senior manager in the service sector. The sample included managers at the top, medium, and shop floor level managers having at least a minimum five-year service experience. The reason behind selecting a specific service length manager was with the assumption that these managers will have better assimilation of the questionnaires because of their experience as a manager. A total of 146 respondents could complete the questionnaires out of 185 distributed instruments.

Samples from Malaysia are drawn from five manufacturing industries and two industries from the 
service sector. The samples were randomly selected from the top, middle, and lower-level management from each industry. Respondents were confident to answer the questionnaire in English. A total of 179 respondents out of 185 distributed instruments could correctly answer the queries. A total of 370 instruments were distributed in both the countries and 325 instruments were useable, making it $87.83 \%$, which is entirely satisfactory. In this study, the obtained Cronbach's a for the overall scale was 0.784, and the reliability coefficients for the subscales PPDM scale were .770 while the trust subscale accounted for .641 .

\section{FINDINGS AND DISCUSSION 4.1 Descriptive Statistics}

Samples were distributed across three management levels in both samples, where lower and middle managers comprising the largest groups. The age ranges from 28 years to 59 years. The average age for the composite sample group was 40.741 , with a standard deviation of 6.65 . The number of female respondents was more in Malaysia (35 out of 179) than in Bangladesh (15 out of 146). A summary of various statistics is shown in Table 1. From this table, two deductions can be drawn. The first is that female participation in a managerial role in Malaysia is more than that of Bangladesh. The second is that the respondent was mostly middle and lower-level managers whose view on PDM is fundamental since these groups play a vital role in the decision-making process.

Table 1 The Samples: Frequency and Descriptive Data

\begin{tabular}{|c|c|c|c|c|}
\hline Description & Frequencies & $\begin{array}{c}\text { Composite } \\
\text { (n-325) }\end{array}$ & $\begin{array}{c}\text { Malaysia } \\
\text { Only } \\
\text { (n-179) }\end{array}$ & $\begin{array}{c}\text { Bangladesh } \\
\text { Only } \\
\text { (n-146) }\end{array}$ \\
\hline \multirow{2}{*}{ Gender } & Male & 275 & 144 & 131 \\
\cline { 2 - 5 } & Female & 50 & 35 & 15 \\
\hline \multirow{3}{*}{$\begin{array}{c}\text { Management } \\
\text { Level }\end{array}$} & Top & 31 & 19 & 12 \\
\cline { 2 - 5 } & Middle & 184 & 99 & 85 \\
\cline { 2 - 5 } & Lower & 110 & 61 & 49 \\
\hline \multicolumn{4}{|l}{ Source: Primary Data }
\end{tabular}

Table 2 portrays that the average age is almost the same in both the countries and service experience varies very little.

\begin{tabular}{|c|c|c|c|c|c|c|}
\hline Description & \multicolumn{2}{|c|}{$\begin{array}{c}\text { Composite } \\
\text { (n-325) }\end{array}$} & \multicolumn{2}{c|}{$\begin{array}{c}\text { Malaysia Only } \\
\text { (n-179) }\end{array}$} & \multicolumn{2}{c|}{$\begin{array}{c}\text { Bangladesh Only } \\
\text { (n-146) }\end{array}$} \\
\hline \multirow{2}{*}{ Age } & Mean & $\begin{array}{c}\text { Std. } \\
\text { Deviation }\end{array}$ & Mean & $\begin{array}{c}\text { Std. } \\
\text { Deviation }\end{array}$ & Mean & $\begin{array}{c}\text { Std. } \\
\text { Deviation }\end{array}$ \\
\cline { 2 - 7 } & 40.71 & 6.65 & 40.65 & 6.83 & 40.79 & 6.45 \\
\hline Service Experience & 4.51 & 1.17 & 4.55 & 1.18 & 4.47 & 1.16 \\
\hline
\end{tabular}

\subsection{Inferential Statistics}

The data were found normally distributed; therefore, an independent samples t-test was conducted to compare the level of PPDM demonstrated by Malaysian and Bangladeshi samples. There was a significant difference in scores between the two groups $(\mathrm{p}<0.05$ in all four dimensions). The Malaysian samples scored higher than Bangladeshi samples along all four dimensions of PDM (see Table 3 and 4 for detail information). The test proofed that the assumption of $\mathrm{H}_{1}$ is supported rejecting the null hypothesis. Malaysian managers have more propensity for a consensus decision-making process in all four dimensions of PDM. 
Table 3 Mean Comparison

\begin{tabular}{|c|l|c|c|c|}
\hline \multicolumn{5}{|c|}{ Group Statistics } \\
\hline & Country & N & Mean & Std. Deviation \\
\hline \multirow{2}{*}{ Org_Eff } & Bangladesh & 146 & 23.1781 & 5.34685 \\
\cline { 2 - 5 } & Malaysia & 179 & 24.9497 & 4.57187 \\
\hline \multirow{2}{*}{ Org_Cul } & Bangladesh & 146 & 20.2055 & 3.81272 \\
\cline { 2 - 5 } & Malaysia & 179 & 22.8659 & 3.78998 \\
\hline \multirow{2}{*}{ Trust } & Bangladesh & 146 & 16.6027 & 3.94353 \\
\cline { 2 - 5 } & Malaysia & 179 & 17.8492 & 3.30213 \\
\hline \multirow{2}{*}{ Power_Share } & Bangladesh & 146 & 28.3699 & 6.46904 \\
\cline { 2 - 5 } & Malaysia & 179 & 31.0056 & 5.54299 \\
\hline
\end{tabular}

Source: Primary Data Analysis

Table 4 Independent Sample t-Test

\begin{tabular}{|c|c|c|c|c|c|c|c|c|c|c|}
\hline \multicolumn{11}{|c|}{ Independent Samples Test } \\
\hline & & \multicolumn{2}{|c|}{$\begin{array}{c}\text { Levene's Test } \\
\text { for Equality } \\
\text { of Variances }\end{array}$} & \multicolumn{7}{|c|}{ t-test for Equality of Means } \\
\hline & & \multirow[b]{2}{*}{$\mathbf{F}$} & \multirow[b]{2}{*}{ Sig. } & \multirow[b]{2}{*}{$\mathbf{t}$} & \multirow[b]{2}{*}{ df } & \multirow{2}{*}{$\begin{array}{l}\text { Sig. (2- } \\
\text { tailed) }\end{array}$} & \multirow{2}{*}{$\begin{array}{c}\text { Mean } \\
\text { Difference }\end{array}$} & \multirow{2}{*}{$\begin{array}{l}\text { Std. Error } \\
\text { Difference }\end{array}$} & \multicolumn{2}{|c|}{$\begin{array}{l}\text { 95\% Confidence } \\
\text { Interval of the } \\
\text { Difference }\end{array}$} \\
\hline & & & & & & & & & Lower & Upper \\
\hline \multirow[t]{2}{*}{ Org_Eff } & $\begin{array}{c}\text { Equal } \\
\text { variances } \\
\text { assumed }\end{array}$ & 3.607 & .058 & 3.219 & 323 & .001 & 1.77164 & .55032 & 2.85429 & 68898 \\
\hline & $\begin{array}{c}\text { Equal } \\
\text { variances not } \\
\text { assumed }\end{array}$ & & & 3.169 & 286.505 & .002 & 1.77164 & .55909 & -2.87209 & .67119 \\
\hline \multirow[t]{2}{*}{ Org_Cul } & $\begin{array}{c}\text { Equal } \\
\text { variances } \\
\text { assumed }\end{array}$ & .003 & .959 & 6.278 & 323 & .000 & 2.66044 & .42378 & -3.49417 & 1.82672 \\
\hline & $\begin{array}{c}\text { Equal } \\
\text { variances not } \\
\text { assumed }\end{array}$ & & & 6.274 & 309.267 & .000 & 2.66044 & .42404 & 3.49482 & -1.82607 \\
\hline \multirow[t]{2}{*}{ Trust } & $\begin{array}{c}\text { Equal } \\
\text { variances } \\
\text { assumed }\end{array}$ & 3.164 & .076 & 3.101 & 323 & .002 & 1.24642 & .40193 & 2.03715 & -.45569 \\
\hline & $\begin{array}{c}\text { Equal } \\
\text { variances not } \\
\text { assumed }\end{array}$ & & & 3.046 & 282.901 & .003 & 1.24642 & .40919 & 2.05186 & -.44099 \\
\hline \multirow[t]{2}{*}{$\begin{array}{l}\text { Powrer } \\
\text { Sharing }\end{array}$} & $\begin{array}{c}\text { Equal } \\
\text { variances } \\
\text { assumed }\end{array}$ & 4.926 & .027 & 3.955 & 323 & .000 & 2.63572 & .66648 & 3.94690 & -1.32454 \\
\hline & $\begin{array}{c}\text { Equal } \\
\text { variances not } \\
\text { assumed }\end{array}$ & & & 3.893 & 286.862 & .000 & 2.63572 & .67696 & -3.96817 & 1.30328 \\
\hline
\end{tabular}

The second hypothesis was to test the relationship between trust and PPDM. A Pearson product-moment correlation coefficient was computed to assess the relationship between the attitude of managers of both the countries (see table 5 and 6). There was a positive correlation between the two variables, $\mathrm{r}=0.392, \mathrm{n}=325, \mathrm{p}=0.000$. Overall, there was a medium $\{(.392 * .392)=0.1536$ or
$15.36 \%$ positive correlation between trust and PPDM. The higher the level of trust between manager and worker, the higher will be a ones' proclivity for PPDM. Thus we can conclude that the trust dimension of PDM is also a predictor of PPDM. Therefore, we can summerise that $\mathrm{H}_{2}$ is also supported. 
Table 5: Descriptive Statistics

\begin{tabular}{|c|c|c|c|}
\hline \multicolumn{4}{|c|}{ Descriptive Statistics } \\
\hline & Mean & Std. Deviation & $\mathrm{N}$ \\
\hline Trust & 17.2892 & 3.65183 & 325 \\
\hline PPDM & 19.6708 & 3.48621 & 325 \\
\hline
\end{tabular}

Source: Primary Data Analysis

Table 5: Correlations

\begin{tabular}{|c|c|c|c|}
\hline \\
\hline & & Trust & PPDM \\
\hline \multirow[t]{3}{*}{ Trust } & Pearson Correlation & 1 & $.392^{* *}$ \\
\hline & Sig. (2-tailed) & & .000 \\
\hline & $\mathrm{N}$ & 325 & 325 \\
\hline \multirow[t]{3}{*}{ PPDM } & Pearson Correlation & $.392^{* *}$ & 1 \\
\hline & Sig. (2-tailed) & .000 & \\
\hline & $\mathrm{N}$ & 325 & 325 \\
\hline
\end{tabular}

Source: Primary Data Analysis

\subsection{Discussion}

From the statistical analysis, we can argue that the Malaysian manager is showing a strong penchant for PDM than Bangladeshi managers. Despite having a similarity in religion, social culture index as maintained by Hofstede, the influence of multinational companies in the national culture, mangers at Malaysian business organisation have more predisposition for PDM. PDM may be augmented by the trust dimension as this study finds a relationship between trust and PPDM. Trust is believed to be an essential dimension of PDM culture in any nation. The result of this study did not find any relation between age and service experience of managers that may have some influence on one's predisposition for PDM.

\section{CONCLUSION AND GUIDELINE FOR FUTURE RESEARCH}

PDM in any organisation is crucial for increasing productivity. The PPDM scale appears to provide a valid measure of the propensity for participative decision making in Malaysia and Bangladesh. Malaysian managers have shown a high-level score in propensity scale seem to have incorporated participative decision-making approaches as a means of improving their organisational effectiveness and productivity. Entrepreneurs in Bangladesh might get some crucial information from this study as to the predisposition required for the adaption of rejection of PDM in their business. There are certain limitations to this study. The number of samples should have been more, and the trust dimension of PDM should have been studied more with another dimension to find out the generalizability. The researcher came across some problems with the language of the instrument while dealing with Malaysian Managers at a lower level. However, mid- level and senior managers' cooperation and assistance helped to overcome this impediment.

Several realistic avenues have been identified for future research. The present study provided general support for the PPDM study initiated by Parnell and Crandall (1994), but further modifications may be appropriate considering other important dimensions like job satisfaction, codetermination, and gender issues.

\section{REFERENCES}

1. Adams, Barbara D., Jessica A. Sartori, Carol Mccann, and Barbara D. Adams. 2006. "Validating the Trust in Teams and Trust in Leaders Scale." Human System (January).

2. Al-Amin, Md, Md Faisal Maruf, Shezanul Haq, and Abu Sayed Wali. 2018. "Employee Engagement Drivers in Bangladesh: A Case Study of Foreign and Local Pharmaceutical Companies." Australia and New Zealand Journal of Social Business, Environment and Sustainability 5(1):46-63.

3. Ali, M. R., A. Khaleque, and M. Hossain. 1992. "Participative Management in a Developing Country: Attitudes and Perceived Barriers." Journal of Managerial Psychology 7(1):11-16.

4. Alsughayir, Abdulrahman. 2016. "Employee Participation in Decision-Making (PDM) and Firm Performance." International Business Research 9(7):64.

5. Arumugam, Subramaniyam and Nimalathasan Balasundaram. 2010. "Industrial Relation System: Lessons for Bangladesh and Sri Lanka from the Japanese Perspective." Petroleum-Gas University of Ploiesti BULLETIN LXII(1):52-60.

6. Black, J. Stewart and Hal B. Gregersen. 1997. "Participative Decision-Making: An Integration of Multiple Dimensions. " Human Relations 50(7):85978.

7. Carolyne, Walubengo N. 2014. "Perceived Factors Affecting Employee Participation in Policy Formulation At the Baraka Health Centre Mathare Slums Nairobi, Kenya." The University of Nairobi. 
8. Chan, Shiau Wei, Abdul Razak Omar, R. Ramlan, Siti Sarah Omar, Khan Horng Lim, and Izzuddin Zaman. 2016. "Assessing Participation in DecisionMaking among Employees in the Manufacturing Industry." ICIMSA 2016 - 2016 3rd International Conference on Industrial Engineering, Management Science and Applications (c):1-5.

9. Cheng, Hong, Feifei Song, and Dandan Li. 2017. "How Middle Managers ' Participation in Decision-Making Influences Firm Innovation Performance: Evidence from China EmployerEmployee Data." Chinese Management Studies, 11(1).

10. Cotton, John L. Jhon L., David A. Vollrath, Kirk L. Krik L. Kirk L. Froggatt, Lengnick-hall Mark L., Jennings Kenneth R., Mark L. Lengnick-Hall, and Kenneth R. Jennings. 1988. "Employee Participation: Diverse Forms and Different Outcomes" edited by S. Ivanko, Dr The Academy of Management Review 13(1):8-22.

11. Driscoll, James W., 1977. Trust and Participation in Organisational Decision Making as Predictors of Satisfaction. WP 898-77. Massachusetts.

12. Dutta, Bipasha and Kazi Maruful Islam. 2016. "Role of Culture in Decision Making Approach in Bangladesh: An Analysis from the Four Cultural Dimensions of Hofstede." Bangladesh E-Journal of Sociology 13(2):30-39.

13. Elele, Joyce and Dail Fields. 2010. "Participative Decision Making and Organizational Commitment." Cross-Cultural Management: An International Journal 17(4):368-92.

14. Farhana, Rashid and Cheazlantaib. 2018. "An Analysis of Human Resource Management Practices in Bangladesh Ready-Make Garments Sector. " Pp. 14-20 in Proceedings of 97th The IRES International Conference. Pattaya: The IRES.

15. Hasan Riyadh, Md. Hamed and Sonia Zaman. 2016. "Labor Law Practice in Bangladesh: A Comparative Study between Local/ Govt. Organisations and Foreign Organizations/MNCs Operating in Bangladesh." IOSR Journal of Business and Management 18(09):21-29.

16. Hossan, Chowdhury Golam, Md. Atiqur Rahman Sarker, and Rumana Afroze. 2012. "Recent Unrest in the RMG Sector of Bangladesh: Is This an Outcome of Poor Labour Practices?" International Journal of Business and Management 7(3):206-18.

17. Islam, Md Enamul, Yasmin Mst Nilufar, and Farooq Mohammad. 2018. "Corporate Social Responsibility of RMG Industry to Secure Future Vulnerability on Workers Retired Life." Global Journal of Management and Business: A Administration and Management 18(7):1-15.

18. Islam, Saiful, and Sharmin Akter Eva. 2017. "Application of Mcgregor's Theory $X$ and Theory $Y$ : Perception of Management toward the Employees in the Banking Industry of Bangladesh." The International Journal Of Business \& Management 5(11):135-45.

19. Kazi, Shaidul. 2009. "Managerial Decision-Making Style: India, Bangladesh, and Finland. Cultural Side of the Game." Tampere University of Applied Sciences Review 12(1):1-8.

20. Khandakar, Shariful Alam, Huq Khadija, and Sultana Sarmin. 2018. "Perception of Employees Regarding Participation in Decision Making and Problem Solving : A Study On Different Branches of
Banks in Dhaka City ." ABC Research Alert 6(1):77-90.

21. Koen, By Vincent, Hidekatsu Asada, Stewart Nixon, Mohamed Rizwan, Habeeb Rahuman, and Abu Arif Mohd Zeid. 2017. All Economics Department Working Papers Are Available at Www.Oecd.Org/Eco/Ecoworkingpapers Member Countries. The Opinions Expressed and Arguments Employed Are Those of the Author ( $S$ ). 1. Latvia.

22. Kumar, S Pavan, and Shilpi Saha. 2017. "Influence of Participation in Decision Making on Job Satisfaction, Group Learning, and Group Commitment: Empirical Study of Public Sector Undertakings in India." Asian Academy of Management Journal 22(1):79-101.

23. Kumar, S. Pavan, and Shilpi Saha. 2017. "Influence of Trust and Participation in Decision Making on Employee Attitudes in Indian Public Sector Undertakings. " SAGE Open 7(3):1-13.

24. M. A. Akkas, Anannay Chakma, and Mohammad Ikbal Hossain. 2015. "Employee-Management Cooperation: The Key to Employee Productivity." Journal of US-China Public Administration 12(2):81-88.

25. Mahboob, Md Alam. 2017. "The Impact of National Culture on the Organizational Culture: Multinational Companies Doing Businesses in Developing Countries." Thesis Archive, University of Gavle.

26. Mahmood, Monowar and Mir Mohammad Nurul Absar. 2015. "Human Resource Management Practices in Bangladesh: Current Scenario and Future Challenges. " South Asian Journal of Human Resources Management 2(2):171-88.

27. Md. Nurun Nabi, Islam. Md. Monirul, Tanvir Mahay, and Md. Abdullah Al Hossain. 2017. "Impact of Motivation on Employee Performances: A Case Study of Karmasangsthan Bank Limited, Bangladesh." Arabian Journal of Business and Management Review 7(1):1-8.

28. Menendez, Robert, Daniel e. O'Brien, Lester e. Munson, Barbara Boxer, and Benjamin L. Cardin. 2013. "Worker Safety and Labor Rights in Bangladesh 'S Garment Sector."

29. Miah, Mohammad Khasro and Mahmudul Mohammad Islam. 2017. "Human Resource Management Practices and Organisational Performance: Evidence from Japanese and US Subsidiaries / Joint Venture in Bangladesh." Journal of Human Resource Management XX(1).

30. Milonga-Monga, Jeremy, Melinde Coetzee, F. V. N. Cilliers, Jeremy Mitonga-Monga, Jeremy MitongaMonga, Melinde Coetzee, F. V. N. Cilliers, and Jeremy Mitonga-Monga. 2012. "Perceived Leadership Style and Employee Participation in a Manufacturing Company in the Democratic Republic of Congo." African Journal of Business Management 6(15).

31. Mohammad Nurul, Absar, Azim Mohammad Tahlil, and Aktar Sadia. 2010. "Research on HRM Practices in Bangladesh: A Review of Literature and Directions for Future Studies." Management and Development 27(3):19-33.

32. Mohiuddin, A. K., 2018. "An A-Z of Pharma Industry Review: Bangladesh Perspective." PharmaTutor 6(12):64-78.

33. Nerdinger, Friedemann W. 2008. "Employee Participation and Organizational Culture." 
Zeitschrift Fur Personalforschung 22(2):107-10.

34. Nor, Siti, Adawiyah Azzahra, Khatijah Omar, Mohd Shaladdin Muda, and Jumadil Saputra. 2017. "Time Management and Work Performance among Female Workers in Malaysia." International Journal of Advanced and Applied Sciences Motivation 4(12):273-80.

35. Paine, Katie Delahaye. 2003. "Guidelines for Measuring Trust in Organizations By Guidelines for Measuring Trust in Organisations." IPR Commission on Measurement and Evaluation 2(1).

36. Parasuraman, Balakrishnan. 2007. "An Examination of Employee Participation in the Private Sector: Malaysian Case Studies." 1st ed., University of Wollongong.

37. Parnell, John A., 2010. "Propensity for Participative Decision Making in Latin America: Mexico and Peru." International Journal of Human Resource Management 21(13):2323-38.

38. Parnell, John A. and Edward D. Bell. 1994. "The Propensity for Participative Decision Making Scale. " Administration \& Society 25(4):518-30.

39. Parnell, John A. and William Crandall. 2000. "Rethinking Participative Decision Making." Personnel Review 30(5):523-35.

40. Parnell, John A., Mehmet Koseoglu, and Eric Dent. 2012. "Propensity for Participative Decision Making (PPDM) In Turkey and the USA." SSRN 5(3):278-304.

41. Raida, Abu Baker. 2013. "Understanding Factors Influencing Employee Engagement: A Study of TheFinancial Sector in Malaysia." 1st ed., RMIT University.

42. Ritesh, Verma., Rambir, and Amit Kumar. 2015. "Leadership Behaviour and Employee Participation in Organizational Decision Making." International Research Journal of Management Sociology \& Humanity 6(5):20-32.

43. Russ, Travis, L., 2011. "Theory X/Y Assumptions as Predictors of Managers' Propensity for Participative Decision Making." Management Decision 49(5):823-36.

44. Russ, Travis, L., 2013. "The Relationship between Theory X/Y: Assumptions and Communication Apprehension." Leadership \& Organization Development Journal, 34(3):238-49.

45. Salahuddin, Nasir Mohammad and Salaudin Shahrul Nizam. 2014. "The Impact of Employee Participation Perceptions on Improved Productivity, Teamwork Effectiveness and Organizational Commitment in MNCs : A Malaysian Case Study." Pp. 1-11 in National Symposium \& Exhibition on Business \& Accounting. Kuala Lumpur: MGHR011.

46. Sayed, Mia Md Abu, Nur Md Alam, Farid Ahamd, and Kamal Uddin. 2017. "Footwear Industry in Bangladesh: Implementation of Six Sigma Methodology." Industrial Engineering \& Management 06(02).

47. Scott-Ladd, Brenda and Marshal Verena. 2004. "Participation in Decision Making: A Matter of Context?" A Service Quality Model and Its Marketing Implications 25(4):646-62.

48. Sekaran, Uma and Roger Bougie. 2016. Research Methods for Business. 7th ed. West Sussex: John Wiley \& Sons Ltd.

49. Shaed, Maslina Mohammed, Suraiya Ishak, and Zaimah Ramli. 2015. "Employee s 'Participation in Decision Making ( PDM ): A Literature Survey.”
Malaysian Journal of Society and Space 13(11):142-55.

50. Shakil, Hedayet Islam. 2018. "Policy-Making Process in Bangladesh Policy-Making Process in Bangladesh Introduction: Understood as the Moment in Which Social." (November 2016).

51. Singh, Sharan Kaur Garib. 2009. "A Study on Employee Participation in Decision Making." UNITAR E-Journal 5(1):20-38.

52. Talukder, Majharul, Deborah Blackman, and ABM Abdullah. 2016. "Antecedents of Successful Decision Making: The Role of Experience, Decision Environment and Decision Type." International Review of Business Research Papers 10(2):81-97.

53. Tandin, Chapel. 2015. "Participative Behaviour Of Organisational Leaders: The Perspective Of The Bhutanese Corporate Sector." The Queensland University of Technology.

54. Timming, Andrew, R., 2015. "The 'reach' of Employee Participation in Decision-Making: Exploring the Aristotelian Roots of Workplace Democracy." Human Resource Management Journal 25(3):382-96.

55. Tzafrir, Shay S. and Simon L. Dolan. 2004. "Trust Me: A Scale for Measuring Manager-Employee Trust." Journal of the Iberoamerican Academy of Management 2(2):115-32.

56. Uddin, Mohammad Jasim, Rumana Huq Luva, and Saad Md Maroof Hossain. 2012. "Impact of Organizational Culture on Employee Performance and Productivity: A Case Study of Telecommunication Sector in Bangladesh." International Journal of Business and Management 8(2):63-77.

57. Westhuizen, De Wet, Gail Pacheco, and Don J. Webber. 2012. "Culture, Participative Decision Making and Job Satisfaction." International Journal of Human Resource Management 23(13):2661-79.

58. Zubair, Ali, Mohsin Bashir, Muhammad Abrar, Sajjad Ahmad Baig, and Shaher Yar Hassan. 2015. "Employee's Participation in Decision Making and Manager's Encouragement of Creativity: The Mediating Role of Climate for Creativity and Change." Journal of Service Science and Management 8(June):306-21. 